\title{
Algoritmikus játékok matematikaórán
}

\section{Sarbó Gyöngyi}

Eötvös Loránd Tudományegyetem

\begin{abstract}
„... az »algoritmus« fogalma nemcsak a szellemi müveletek révén megvalósuló tevékenységre alkalmazható, hanem a gyakorlati, fizikai cselekvésekben végbemenő tevékenységre is."
\end{abstract}

Kulcsszavak: fejtörők, feladatok, matematikai játékok, logikai játékok, algoritmusok

Mindennapi életünk szerves részeként nap mint nap hozunk létre olyan ismétlődő eljárásokat, melyeket meghatározott sorrendben, lépésenként hajtunk végre. Az esetek többségében észre sem vesszük, de gyakorlatilag algoritmizációt végzünk. Az algoritmusok az oktatásban is fontos szerepet töltenek be, mivel átalakíthatják a gondolkodási tevékenységek stílusát, rendszerezetté, szervezetté tehetik azt. A most bemutatandó algoritmikus játékok segítségével ösztönözhetjük a gyerekeket a közös okoskodásra, a problémamegoldásra, az alkotó vizsgálódásra, az erőfeszítésre a megoldás megtalálása érdekében. Tapasztalataim szerint ezek a feladatok szokatlan jellegüknek és újszerűségüknek köszönhetően motiváló hatással vannak a gyerekekre.

\section{A fejtörök által nyújtott lehetöségek}

A hagyományos fejtörő-irodalomban létezik egy speciális fejtörőtípus, melynek megoldása nem egy egyszerü szám, hanem egy megoldáshoz vezető „recept”, lépések meghatározott sorrendje, vagyis más néven algoritmus. Az fejtörők e típusát a kanadai származású matematikus, számítógéptudós és filozófus $A$. K. Dewdney nevezete el algofejtörőknek (Dewdney, 1987). sorolom:

A megoldandó probléma természetétől függően az algofejtörőket több csoportba

- Átkeléses feladatok

- Irányítási feladatok

- Méregetős feladatok

- Ösi algofejtörők

\section{Átkeléses feladatok}

Ebbe a feladatcsoportba sorolom azokat a feladványokat, melyekben valamilyen öszszetett feltételrendszernek megfelelően kell egy átkelési problémát megoldani. Minden algofejtörőnél az első feladat a feltételek tisztázása, ellenkező esetben a gyermeki fantázia érdekesebbnél érdekesebb megoldásokkal rukkol elö.

Az átkeléses feladatok kritériumrendszere általában a szereplők társaságára vonatkozik. Például nem lehet a kecske együtt a káposztával, a fegyverhordozó nem lehet idegen lovag társaságában a saját gazdája nélkül, vagy nem lehet több kannibál a parton, mint misszionárius. Ez a feltétel egy hibajelenséget idézhet elő a gyerekeknél,

\footnotetext{
1 Landa, L. N. (1969): Algoritmizálás az oktatásban.Tankönyvkiadó, Budapest.
} 
ugyanis nem mindenki számára egyértelmü, hogy mikor mondhatjuk azt, hogy két szereplő egymás társaságban tartózkodik. A most következő feladatot negyedik osztályos tanulókkal oldottuk meg.

„Történt egyszer, hogy három lovag találkozott a folyóparton, mindegyiket a fegyverhordozója kísérte. Át akartak kelni a folyón a túlsó partra. A nádasban találtak egy kicsi, kétszemélyes csónakot. Az átkelés könnyünek ígérkezett, hiszen a lovak át tudják úszni a folyót. Egy akadály azonban majdnem meghiúsította a vállalkozást. Az összes fegyverhordozó - mintha csak megállapodtak volna - kereken elutasította, hogy ismeretlen lovagok társaságában maradjon a saját gazdája nélkül. Sem rábeszélés, sem fenyegetés nem segített, a gyáva fegyverhordozók makacsul kitartottak álláspontjuk mellett. Végül az átkelést mégis megvalósitották, mind a hat ember szerencsésen átjutott a túlsó partra egy kétszemélyes csónak segítségével. Az átkelés közben betartották a feltételt, amelyhez a fegyverhordozók ragaszkodtak.

Hogyan keltek át a folyón, ha a kétszemélyes csónakon kívül más eszközük nem volt, és a lovak segítségét sem vették igénybe?" (Ignatyev, 1982)

Segítségképpen az alábbi képet vetítettem ki a táblára.

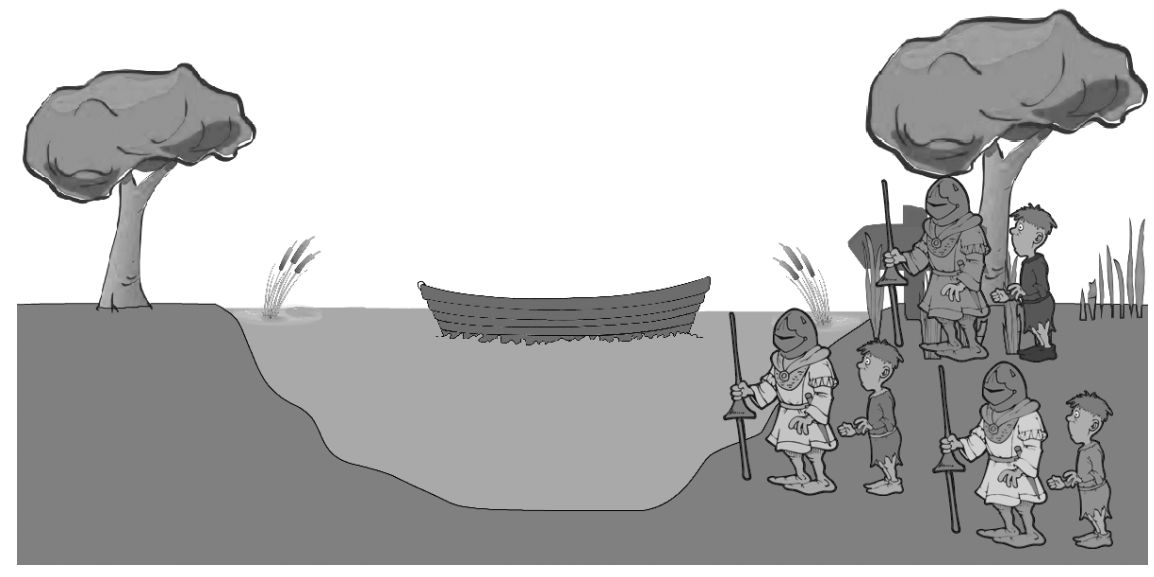

1. ábra: Lovagok és fegyverhordozóik

A képen látható lovagokat és fegyverhordozókat mágneses papírra nyomtattam, ezáltal a sablonos korongok helyett valami újat, a feladat világához közelebb álló szemléltetőeszközt adtam a gyerekek kezébe. A lovak szándékosan nem szerepelnek a mintaképen, mert nagyon megzavarják a tanulókat. Ugyanis ha a lovakat is látják, hajlamosak azok úszótudására támaszkodni. A megoldás elkezdése előtt érdemes tisztázni a következőket:

- az átkeléshez a lovak segítségét nem lehet igénybe venni,

- sem kötelük, sem más segédeszközük nincs,

- mikor kerül a fegyverhordozó idegen lovag társaságába.

Megfigyeltem, hogy először a tanulók azonos személyeket raknak össze a csónakba - fegyverhordozót fegyverhordozóval, és lovagot lovaggal - majd elakadtak a megoldásban. A folytatáshoz csak annyi segítség kellett, hogy tisztázzuk, mit jelent az idegen lovag társasága.

A feladat megoldásának rögzítése nehezen ment. A gyerekek szerint túl sokat kell írni, ezért ennek elkerülése érdekében inkább rajzolnak. A végeredmény átláthatatlan, összenyilazott, kesze-kusza rajz lett, melynek megfejtése még a készítőnek is okozott némi fejtörést. Rajzos megoldásokhoz a következő módszer alkalmazását javaslom (Lukács és Tarján 1958 alapján): 


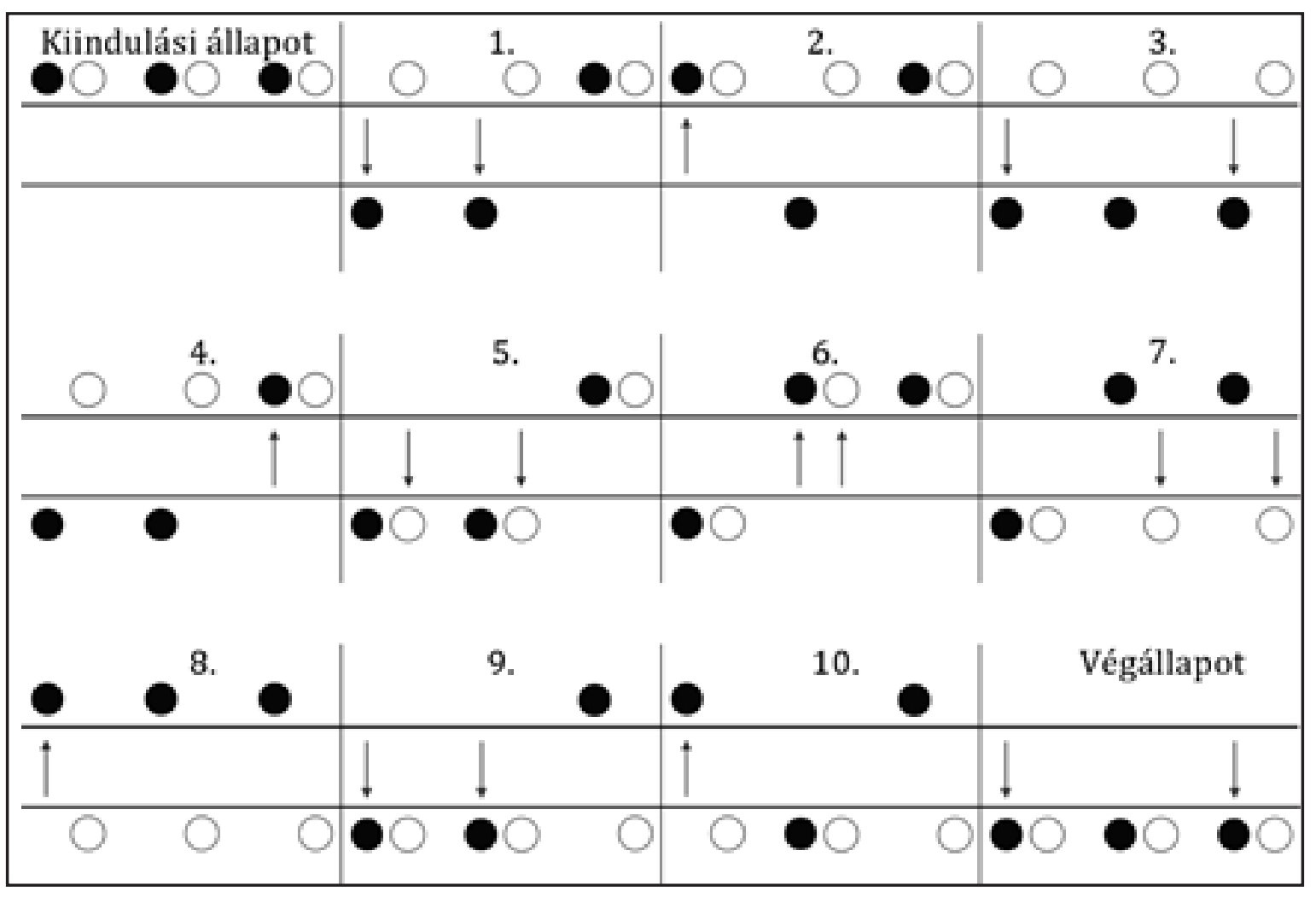

2. ábra: Javaslat az átkeléses feladatok megoldásának rögzítésére

Fekete körök jelzik a fegyverhordozókat, fehérek a lovagokat és a nyilak mutatják az átkelés irányát. Az ábra megkönnyíti az aktuális állapot áttekintését, segít a feladat megoldásának folytatásában, továbbá egyértelműen leolvashatóak a megoldási lépések.

$A z$ interneten is fellelhetők algofejtörő feladatatok flashjátékok formájában. Sok közülük interaktív táblán is tökéletesen használható. A fentebb említett misszionárius és kannibálok fejtörő a következő linken érhető el: http://www.novelgames.com/en/ spgames/missionaries/

\section{Irányítási feladatok}

Ebbe a feladatcsoportba sorolom azokat a feladványokat, melyekben különféle közlekedési problémákból kell megtalálni a kiutat. Többségében vasúti feladatokról van szó, ahol vagy vonatok közlekednek különféle sínpályákon, vagy egy leleményes mozdonyvezetőnek kell a vagonokat elrendezni, de találkozhatunk hajókkal és autókkal kapcsolatos feladványokkal is. Talán a terepasztalnak és a kisvonatokkal való játéknak köszönhetően ez az a feladatcsoport, mely a legközelebb áll a gyerekekhez.

Ezeknél a feladatoknál célszerű tisztázni, hogy a mozdony hogyan tudja a vagonokat mozgatni. Favasút segítségével modelleztük a következő feladványt.

„Egy magányos mozdony önmagába visszatérő sínhurokhoz ér, amelyre állítható váltón át lehet behajtani. A hurokszakaszon két üres kocsi áll, amelyek közt egy híd található. A híd egy kocsit elbir, de a mozdonyt már nem, és nem hosszabb egy vasúti kocsinál. A mozdonyvezetönek meg kell cserélni a két kocsit úgy, hogy a munka végeztével el tudja hagyni a körpályát.

A feladat megoldásának feltétele: a mozdony és a kocsik mindkét végén kapcsoló berendezés van. A vonatokat fékezők kísérik, akik a szükséges szétés összekapcsolásokat utasításainknak megfelelően elvégzik (csak álló szerelvény esetén). A vasúti jármüveket kímélni kell, ezért a kocsikat a mozdony 
ütközéssel nem gurithatja el, csak vonatással lehet helyet változtatni." (Dewdney, 1987)

Hogyan oldja meg a feladatot a mozdonyvezető?

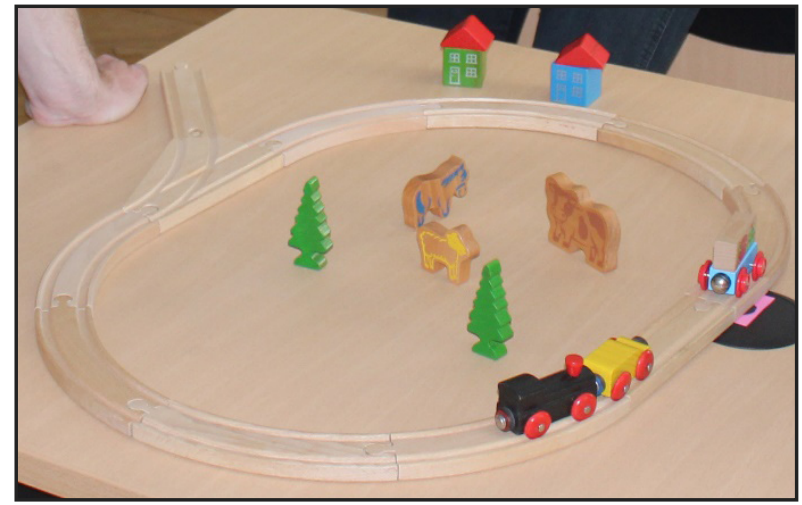

5. ábra: Favasút a projekt héten

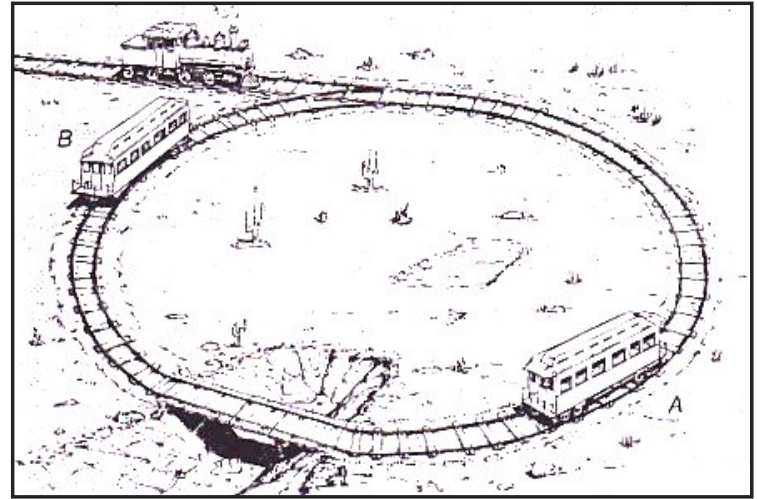

6. ábra: A feladat eredeti ábrája

A feladatban nem a két kocsi megcserélése okozott problémát, hanem az, hogy utána a mozdonynak el kellett hagynia a körpályát. Gyakran ragadt be a mozdony a híd és az egyik kocsi közé. Sokan nem gondoltak arra a lehetőségre, hogy a vagont, nemcsak az egyenes szakaszon, hanem a hídon is lehet hagyni. Ezáltal át tudjuk vinni a mozdonyt a vagon egyik oldaláról a másikra, így elkerülve a mozdony beragadását.

\section{Megoldás}

1. A mozdony összekapcsolódik az A kocsival, és rátolja a hídra. Itt szétkapcsolódnak.

2. A mozdony elpöfög a B kocsiig, összekapcsolódnak, és eltolja B-t az A kocsiig, majd összekapcsolódnak.

3. A mozdony kiviszi a két kocsit az egyenes szakaszra (sorrend: ABM)

4. Az A kocsit lekapcsolják.

5. A mozdony a B kocsit rátolja a hídra, itt lekapcsolják.

6. A mozdony kimegy az A kocsiért, és betolja a helyére, itt lekapcsolják.

7. A mozdony elpöfög a B kocsiig, aki még mindig a hídon áll, hozzákapcsolják a mozdonyhoz, és behúzza a helyére. Lekapcsolják a B kocsit a mozdonyról.

8. A mozdony elhagyja a körpályát.

\section{Méregetős feladatok}

Ebbe a feladatcsoportba sorolom azokat a feladványokat, melyekben vödrök, kancsók, homokórák és mérlegek segítségével kell a megoldást megtalálni. Például különböző űrtartalmú vödrök segítségével kell adott mennyiségű vizet hozni a folyóból, különböző homokórákat forgatva kell időt mérni, vagy egy kétkarú mérleg segítségével kell a csak a súlyában különböző, hamis pénzérmét megtalálni.

Ennél a feladattípusnál találkoztam a legkevesebb félreértéssel. Általában nincs probléma a feladat értelmezésével, csak a megoldás rögzítésével. A következő feladatot negyedik osztályos tanulókkal oldottuk meg. A tanulók hatfős csoportokban dolgoztak.

Van egy 8 deciliteres kancsód tele tejjel. Ezen a kancsón kívül van még egy üres 5 és egy üres 3 deciliteres kancsód is. 


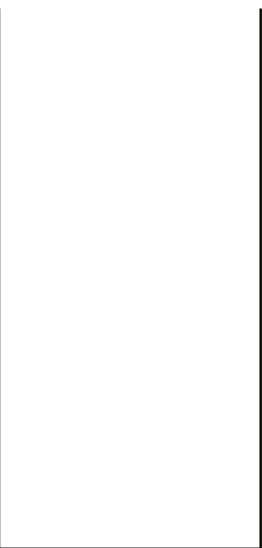

8 deciliter

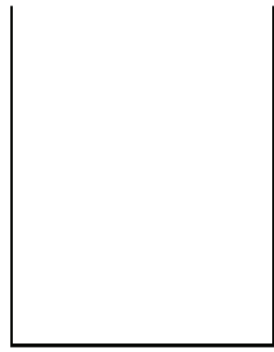

5 deciliter

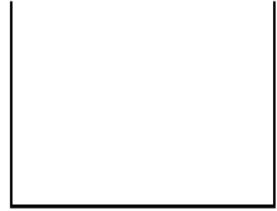

3 deciliter

7. ábra. A kancsókat szimbolizáló ábra, melyekbe elhelyezhetjük az egybevágó téglalapokat

„Hogyan tudsz a kancsók segítségével 4 deciliter tejet kimérni, ha a tej nem folyhat ki a kancsókból, nem lehet kiborítani, és a kancsókon kívül más eszközt vagy méröedényt nem használhatsz?" (Katona, 2007)

A munka elkezdése előtt fel kell hívni a gyerekek figyelmét arra, hogy a 8 deciliteres kancsó tele van, a tejet nem lehet kiönteni és nem folyhat ki a kancsókból. A megoldást segítheti, ha egybevágó téglalapok segítségével szemléltetjük az egyes edényekben lévő tej mennyiségét. A tanulók között sétálva feltűnt, hogy mindenki annál a lépésnél akadt el, amikor mindhárom kancsóban van valamennyi tej. Megkérdeztem tőlük, hogy két kancsó tartalmát össze lehet-e önteni. Ennek hatására megszületettek az első jó megoldások.

A megoldások rögzítésekor a legnagyobb problémát az okozta, hogy a tanulók mindig kiradírozták, hogy előzőleg mennyi tej volt a kancsókban. Keveseknek jutott eszébe, hogy a különböző állapotokat külön rajzokon ábrázolja. Célszerű egy üres táblázatot készíteni a megoldások rögzítésére.

\section{Megoldás}

\begin{tabular}{|c|c|c|c|}
\hline & 8 deciliteres & 5 deciliteres & 3 deciliteres \\
\hline 1. átöntés & 5 & 0 & 3 \\
\hline 2. átöntés & 5 & 3 & 0 \\
\hline 3. átöntés & 2 & 3 & 3 \\
\hline 4. átöntés & 2 & 5 & 1 \\
\hline 5. átöntés & 7 & 0 & 1 \\
\hline 6. átöntés & 7 & 1 & 0 \\
\hline 7. átöntés & 4 & 1 & 3 \\
\hline \multicolumn{2}{|c|}{ A 4 deciliter tej a 8 deciliteres kancsóban lesz. } \\
\hline
\end{tabular}

\section{Ősi algofejtörök}

Itt az olyan régi fejtörőkre gondolok, mint a Hanoi tornyai, de Brahma tornyai vagy Világvége feladvány néven is találkozhatunk vele. Valamint ide sorolom a dámajá- 
ték által ihletett algofejtörőket, melyekben a korongok egy meghatározott sorrendjéből különféle lépési szabályokat betartva a korongokkal lépkedve el kell jutni egy adott végállapotba.

A dámás játékoknál érdemes a lépési szabályokat ábrával is szemléltetni. A dámás játékok közti különbségek a dámák számában, az elérendő mintában, a lépések szabályaiban és a lépések számban nyilvánulnak meg. Kiköthetjük például, hogy az adott feladatot négy lépésben kell megoldani.

Nézzünk példát a dámajátékra.

'Két fekete és két fehér dámafigurát az ábrának megfelelöen helyezünk el. Az a feladatod, hogy a fekete és fehér korongokat felcseréld (tehát az 1, 2 jelü mezőkön álló korongok kerüljenek a 4, 5 jelű mezőkre), az alábbi szabályi betartásával:

1. Fehér figurával kell kezdeni az áthelyezést.

2. Mindegyik figurát csak szomszédos mezöre lehet tenni, vagy egy mezöt lehet átugrani (többet nem).

3. Egyik figurát sem lehet visszatenni olyan helyre, ahol már volt.

4. Egy mezőn csak egy figura állhat.

Hogyan oldanád meg a feladatot?" (Ignatyev, 1982)

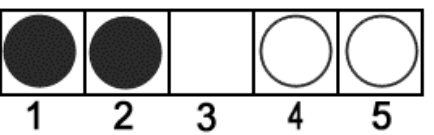

KIINDULÁSI ÁLLAPOT

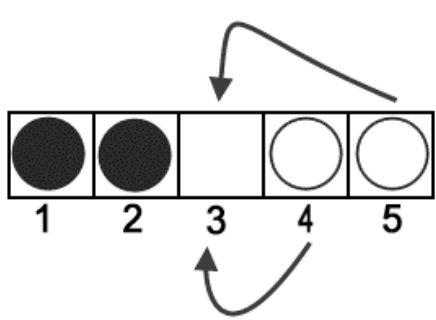

A JÓ KEZDÉS

\section{Megoldás}

\begin{tabular}{|c|c|c|c|}
\hline $\begin{array}{l}\text { 1. lépés: 4-es a 3-as } \\
\text { helyre }\end{array}$ & & $\begin{array}{l}\text { 5. lépés: } 5 \text {-ös a 3-as } \\
\text { helyre }\end{array}$ & \\
\hline $\begin{array}{l}\text { 2. lépés: } 2 \text {-es a } 4 \text {-es } \\
\text { helyre }\end{array}$ & & $\begin{array}{l}\text { 6. lépés: 4-es az 5-ös } \\
\text { helyre }\end{array}$ & 1 \\
\hline $\begin{array}{l}\text { 3. lépés: } 1 \text {-es a 2-es } \\
\text { helyre }\end{array}$ & 12 & $\begin{array}{l}\text { 7. lépés: 2-es a 4-es } \\
\text { helyre }\end{array}$ & $\begin{array}{ll}12 \\
\end{array}$ \\
\hline $\begin{array}{l}\text { 4. lépés: 3-as az 1-es } \\
\text { helyre }\end{array}$ & $\begin{array}{lll}1 & 2\end{array}$ & $\begin{array}{l}\text { 8. lépés: } 3 \text {-as a 2-es } \\
\text { helyre }\end{array}$ & 123 \\
\hline
\end{tabular}

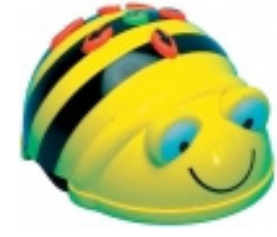

A Bee-Bot által nyújtott lehetőségek

A Bee-Bot egy kifejezetten gyerekek számára fejlesztett padlójáró robotméhecske. Gyerekbarát dizájn és könnyü kezelhetőség jellemzi. 
Ez a kis robot képes előre és hátra menni egy egységet - ezek $15 \mathrm{~cm}$-es lépések -, jobbra és balra fordulni $90^{\circ}$-ot, valamint villogó szemmel és hanggal jelzi, ha egy utasítást végrehajtott, vagy végére ért a kiadott utasítássorozatnak. A méhecske memóriájában egyszerre 40 lépés tárolható. A lépések hosszának ismeretében könnyen tudunk különféle pályákat készíteni a robothoz, és a gyerekeket is bevonhatjuk ebbe a munkába.

A Bee-Bot használatba vétele előtt fontos tisztázni a gyerekekkel, hogy a robot hogyan müködik. A mozgás gyakorlásához - későbbiekben az útvonal megtervezéséhez - elhelyezhetünk a pályára nyilakat, melyek segítségével előre megtervezhetővé válik a méhecske útvonala. Utána már csak annyi a dolgunk, hogy ugyanolyan sorrendben megnyomjuk a gombokat és leellenőrizzük, hogy a robot tényleg az általunk megtervezett pályát járja-e be. A gyerekek viselkedésére az elején jellemző, hogy minden gomb lenyomása után pakolgatják a robotot a megfelelő mezőre és irányba.

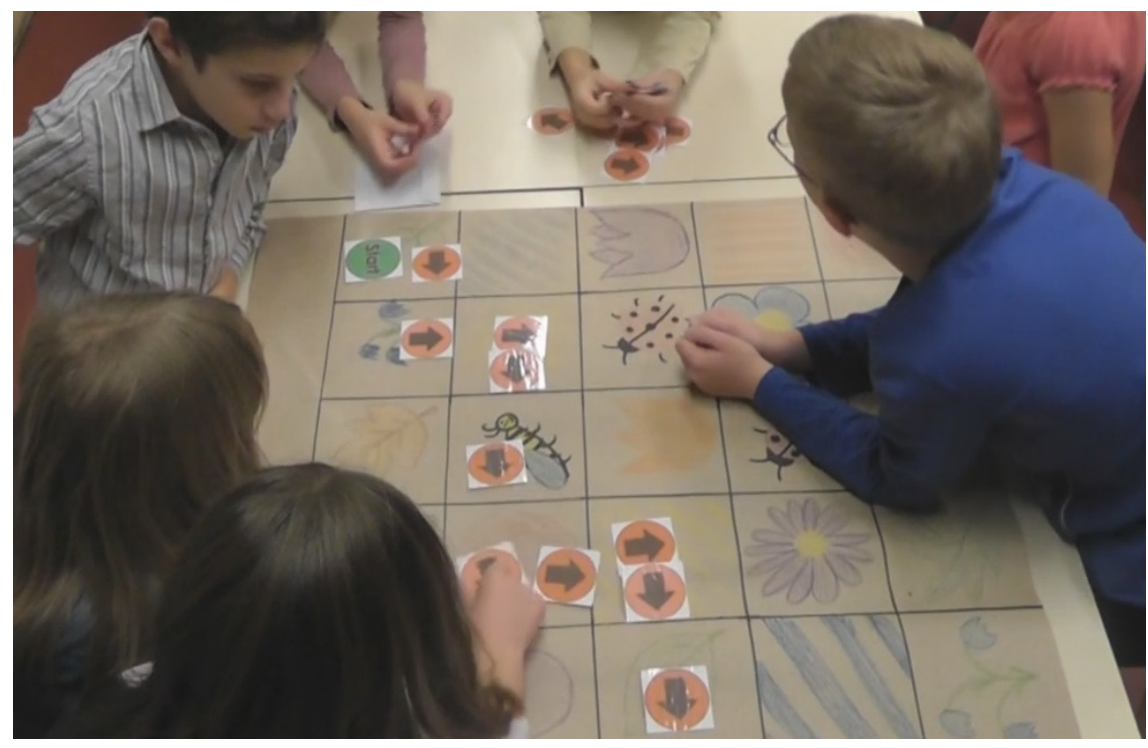

8. ábra. Nyilak a pályán

Különböző nehézségű feladatokat tudunk megvalósítani a pályák segítségével:

- jussunk el egyik mezőről a másikra,

- haladjunk végig a mezőkön egy adott sorrenden, például különböző tevékenységek lépései vannak összekeveredve a pályán, meg kell keresni az összetartozókat és a jó sorrendben megállni rajtuk,

- jussunk el egyik mezőről a másikra, de közben bizonyos mezőkre nem léphetünk,

- jussunk el egyik mezőről a másikra, de közben érintsünk bizonyos mezőket, akár az érintendő mezők sorrendjét is megadhatjuk,

- jussunk el egyik mezőről a másikra, de a tiltott mezők elzárják elölünk a célt, viszont ha egy másik mezőre rálépünk, olyan „képességet” szerezhet a méhecskénk, mellyel át tud haladni a tiltott mezőkön is.

A feladatok megoldása közben, ha a gyerekek csoportban dolgoznak megfigyelhető, hogy felosztják egymás között a munkát, például mindenki egy gombot nyom le a méhecske hátán és így mennek körbe. Észreveszik az útvonalak közti különbségeket és közösen tervezik meg a megoldást (Pasaréti és Sarbó, 2013). 


\section{A logikai játékok által nyújtott lehetőségek}

A ThinkFun nevű cég 1985-ben alapult és piacvezető a logikai játékok gyártásában. Az évek során több díjnyertes játékot is kifejlesztettek. A cég ikonikus játéka a Rush Hour, amit ma már mobilalkalmazásként is elérhetünk. Csak néhány algoritmikus játékot emelnék ki a hatalmas kínálatból. A játékok mindegyikére jellemző, hogy a kezdőtől a haladóig mindenki számára találhatunk feladatokat.

Rush Hour (Csúcsforgalom) és annak különböző változatai

- Rush Hour Junior

- Rush Hour Safari

- Railroad Rush Hour

River Crossing

TipOver

Hoppers

Összességében elmondható, hogy a kisiskolás korosztály tanulói kifejezetten szeretik az algofejtörő feladatokat, és egy feladattal átlagosan 10-15 percet foglalkoznak. Döntésüket azzal indokolják, hogy ezeken a feladatokon lehet gondolkodni, és rossz vagy hiányzó lépés esetén nem jutnak el a megoldáshoz. Élő tanórai alkalmazásban a megoldást segítik a makettek, korongok, bábuk alkalmazása vagy a szerepek eljátszása.

A gyerekekkel való fogalkozások során egyértelművé vált számomra, hogy az algofejtörők használata jelentős pedagógiai hatással voltak a tanulókra.

1. Rájöttek, hogy a módszer müködik, meg tudták oldani a kezdetben nehéz feladatokat.

2. A megoldás sikerélményt nyújtott nekik.

3. Kialakult az igény egy újfajta gondolkodási módszerre: a későbbiekben, ha elakadtak a megoldásban, nem kértek segítséget, nem kezdték elölröl a feladatot, hanem egy-egy lépést módosítottak.

\section{Irodalom}

Dewdney, A. K. (1987): Számítógépes észjáték. Tudomány,, 8. sz.

Ignatyev, Jemeljan Ignatyevics (1982): A találékonyság birodalmában. Tankönyvkiadó, Budapest.

Iványi Antal (2005): Párhuzamos algoritmusok.ELTE Eötvös Kiadó, Budapest. http://compalg. inf.elte.hu/ tony/Elektronikus/Parhuzamos/P1H.xml

Hvorecký, Jozef, Kelemen, Jozef (1978): Ötlettől az algoritmusig. Tankönyvkiadó, Budapest.

Katona Renáta (2007, szerk.): Logikai egypercesek.DFT-Hungária Kft, Budapest.

König Dénes (1992): Matematikai mulatságok II.Typotex Kiadó, Budapest.

Landa, L. N. (1969): Algoritmizálás az oktatásban. Tankönyvkiadó, Budapest,.

Lukács Ernőné - Tarján Rezsőné (1958): Tarkabarka matematika.Bibliotheca Kiadó, Budapest.

Pasaréti Otília - Sarbó Gyöngyi (2013): Robotika mühely: Bee-Bot gyakorlati tapasztalatok kisgyermekkorban. Konferenciaelőadás (INFO Éra), Zamárdi, 2013.

Róka Sándor (2007): Hány éves a kapitány?Typotex Kiadó, Budapest.

Vassné Varga Edit (1992): Algofejtörők - egy eszköz a gondolkodás fejlesztésére. In: Lengyelné Dr. Szilágyi Ágnes (1992, szerk.) Budapesti Tanitóképzö Föiskola Tudományos közleményei XII. Budapest, 1992, 71-86. 